\title{
PERANCANGAN SISTEM INFORMASI PENGELOLAAN LAPORAN KEUANGAN NAGARI PARIT MALINTANG KABUPATEN PADANG PARIAMAN DENGAN MENGGUNAKAN BAHASA PEMROGRAMAN JAVA
}

\author{
Eko Amri Jaya \\ Sistem Informasi, Sekolah Tinggi Teknologi Industri Padang \\ Email : ekoamrijaya@sttind.ac.id
}

\begin{abstract}
Abstrak : Nagari Parit Malintang merupakan salah satu dari enam puluh nagari (60) yang ada di Kabupaten Padang Pariaman. Saat ini Nagari Parit Malintang menggunakan sistem konvensional dalam pembuatan laporan keuangan yaitu pencatatan pada sebuah buku, kemudian direkap kembali untuk membuat laporan keuangan. Sistem tersebut mempunyai banyak kekurangan diantaranya memungkinkan adanya kesalahan dalam pembuatan laporan keuangan. Maka dari itu dibutuhkan sebuah sistem informasi untuk mempermudah Nagari Parit Malintang dalam pembuatan laporan keuangan. Dengan adanya sistem informasi ini diharapkan dapat mempermudah Nagari Parit Malintang dalam Pengelolaan laporan keuangan yang lebih cepat, tepat efektif dan efisien sehingga dapat menimalisir kesalahan dan mengoptimalkan keamanan data.
\end{abstract}

Kata Kunci : Sistem, Informasi, Laporan keuangan.

Abstract : The village of Parit Malintang is one of sixty villages (60) in Padang Pariaman District. Currently, Parit Malintang village uses conventional system in preparing financial statements that is recording on a book, then recapitalized to make a financial report. The system has many disadvantages such as allowing mistakes in the preparation of financial statements. Therefore required an information system to facilitate the Village Parit Malintang village in preparing financial statements. With this information system is expected to facilitate Parit Malintang village to the management of financial statements more quickly, effective and efficient so as to minimize errors and optimize data security.

Keyword : System, Information, Financial Report

\section{PENDAHULUAN}

Nagari Parit Malintang adalah salah satu nagari di Kecamatan Enam Lingkung Kabupaten Padang Pariaman. Pada tahun 2016 ini nagari Parit Malintang mengelola keuangan nagari sebesar Rp. 1.932.493.005 (satu milyar sembilan ratus tiga puluh dua juta empat ratus sembilan puluh tiga ribu lima rupiah) yang merupakan dana transfer dari pemerintah pusat dan pemerintah daerah serta pendapatan asli nagari lainnya.

Dengan besarnya dana yang dikelola maka nagari dituntut untuk bisa melaksanakan pengelolaan keuangan dengan baik, tepat dan akurat sesuai dengan peraturan yang ada, saat ini pengolahan laporan keuangan Nagari Parit Malintang sudah menggunakan komputerisasi dengan menggunakan sistem microsoft office dan microsoft excel tetapi belum efektif membutuhkan waktu yang lama dan sering terjadi kesalahaan.

Berdasarkan uraian diatas, maka penulis tertarik untuk mengangkat sebuah judul “ Perancangan Sistem Informasi Pengolahan Laporan Keuangan Nagari Parit Malintang Kabupaten Padang Pariaman Menggunakan Bahasa Pemrograman Java", sebagai masalah utama dalam penulisan skripis ini. Dengan tujuan ingin menciptakan sebuah program aplikasi komputerisasi khususnya dalam pengolahan laporan keuangan, 
sehingga sistem yang penulis rancang dapat diterapkan dan dimanfaatkan.

Adapun Batasan Masalah :

1. Pada sistem hanya menyediakan pengolahan laporan keuangan Nagari Parit Malintang Kabupaten Padang Pariaman.

2. Penelitian terhadap pengolahan laporan keuangan Nagari Parit Malintang Kabupaten Padang Pariaman menggunakan bahasa pemrograman Java.

Adapun Rumusan Masalah sebagai berikut:

1. Bagaimana merancang sistem informasi pengolahan laporaan keuangan Nagari Parit Malintang agar bisa memperoleh informasi yang cepat, tepat dan akurat?

2. Bagaimana mengoptimalkan pemanfaatan komputer untuk pengolahan laporan keuangan Nagari Parit Malintang Kabupaten Padang Pariaman

Tujuan Penelitian sebagai berikut :

1. Untuk mendapatkan sistem informasi pengolahan laporan keuangan Nagari Parit Malintang Padang Pariaman dengan cepat, tepat dan akurat.

2. Untuk memudahkan Nagari Parit Malintang dalam pembuatan laporan keuangan.

\section{METODOLOGI PENELITIAN}

Jenis penelitian yang peneliti lakukan adalah penelitian Terapan (Aplplied Reseach). Penelitian terapan adalah penelitian yang hati-hati, sistematis dan terus menerus terhadap suatu masalah dengan tujuan digunakan segera untuk keperluan tertentu. Adapun penjelasan tentang kerangka kerja penelitian atau struktur kerja yang dilakukan dalam penelitian ini sebagai berikut :

1. Pendahuluan Penelitian

Melakukan wawancara dan pengamatan masalah secara langsung untuk mendapatkan data-data yang dibutuhkan.
2. Landasan Teori

Disini penulis juga memberikan penjelasan hal-hal yang berhubungan dalam perancangan sistem berupa pengertian sistem informasi, Pemrograman Java, Data Base MySql

\section{Identifikasi Masalah}

Kerangka kerja ini dimulai dari identifikasi masalah dalam pengelolaan laporan keuangan nagari Parit Malintang, yang bertujuan untuk menjaga konsistensi dari penelitian ini sehingga penelitian ini lebih terarah, sehingga tujuan dari penelitian yang diharapkan dapat tercapai.

4. Perumusan Masalah

Merumuskan suatu permasalahan yang timbul pada proses dengan berbagai tujuan.

\section{Menentukan Tujuan Penelitian}

Berdasarkan pada ruang lingkup masalah dan perumusan masalah yang telah dibuat pada tahap sebelumnya, tahap berikutnya adalah menentukan tujuan penelitian yang bertujuan untuk memperjelas kerangka tentang apa saja yang menjadi sasaran dari penelitian ini.

\section{Pengumpulan Data}

Pengumpulan data dan informasi pada tahap ini dilakukan untuk megetahui mendapatkan data dan informasi yang nantinya akan mendukung penelitian ini, dalam pengumpulan data, terdapat beberapa metode yang digunakan yaitu penelitian lapangan (field research), penelitian perpustakaan (library research), serta penelitan laboratorium (laboratory research).

\section{Menganalisa dan Mendesain Sistem}

menganalisis sistem dapat didefinisikan sebagai penguraian dari suatu sistem informasi yang utuh. Setelah pengumpulan data maka langkah selanjutnya menganalisa dan mendesaian sistem berdasarkan identifikasi masalah dan data yang didapat sehingga menghasilkan suatu informasi yang cepat, tepat dan akurat. Perancangan 
dari model sistem dengan menentukan rancangan input dan informasi apa saja yang dihasilkan nantinya.

\section{Pengolahan Data dengan Java}

Data yang didapat akan diolah dalam pemrograman java untuk mendapatkan informasi dalam pengelolaan laporan keuangan nagari yang cepat, tepat dan akurat.

9. Implementasi Sistem

Selanjutnya peneliti juga akan melakukan implementasi sistem untuk dapat memastikan apakah sistem yang telah dirancang layak atau belum untuk digunakan.

\section{HASIL DAN PEMBAHASAN}

Adapun struktur dalam implementasi sistem antaralain :

1. Perencanaan dan proses implementasi Perencanaan dan proses implementasi merupakan langkah penting dalam penerapan sebuah sistem baru. Tujuan dari pemberlakuan proses ini adalah agar penerapan sistem baru ini betulbetul sesuai dengan tujuan dan sasaran pengadaannya.

2. Kegiatan proses implementasi Adapun kegiatan proses implementasi dalam sistem ini yaitu sebagai berikut :
a. Melatih pengguna (training)
b. Install hardware dan software
c. Perancangan
d. Sistem Analisa
e. Tahap Pengujian
f. Evaluasi

Form menu utama adalah antar muka (interface) yang digunakan sebagai form induk / form utama. Form utama ini akan selalu ditampilkan saat program dijalankan. Untuk lebih jelasnya dapat dilihat pada Gambar :

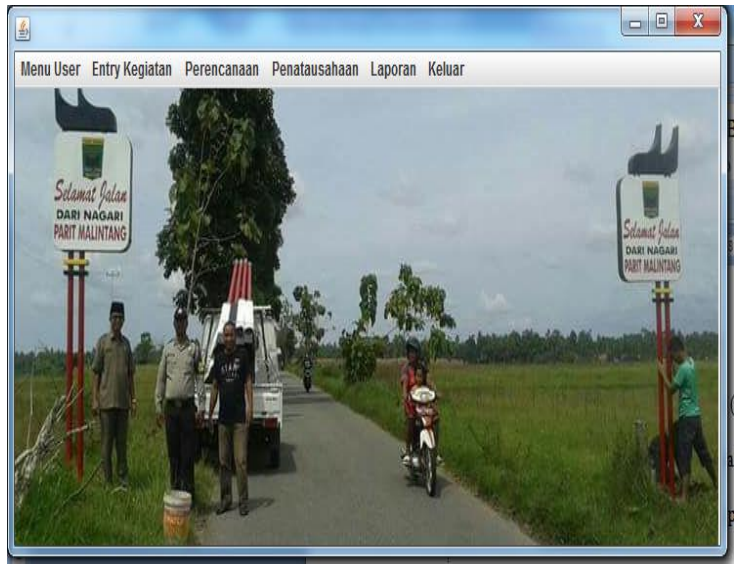

Gambar 1 Tampilan Menu Utama

Menu utama terdiri dari tiga menu yaitu:

Menu User

Pada menu user terdiri dari dua sub menu yaitu:

a. Sub Menu Login

Menampilkan form menu login dimana user harus login terlebih dahulu sebelum memasuki sistem.

\section{b. Sub Menu Tambah User}

Menampilkan form menu entry data user, dimana data-data tersebut akan dimasukkan pada database program.

\section{Pengujian Sistem}

Ini merupakan awal untuk masuk kesistem, dengan kata lain ini merupakan hak akses untuk masuk bagi user. Fungsi dari form login adalah untuk menjaga agar sistem tidak sembarangan orang bisa mengaksesnya demi keamanan data yang ada di dalamnya. Form login untuk sistem informasi pengelolaan laporan keuangan nagari Parit Malintang yang di dalamnya ada beberapa user yang menggunakannya dapat dilihat pada berikut ini : 


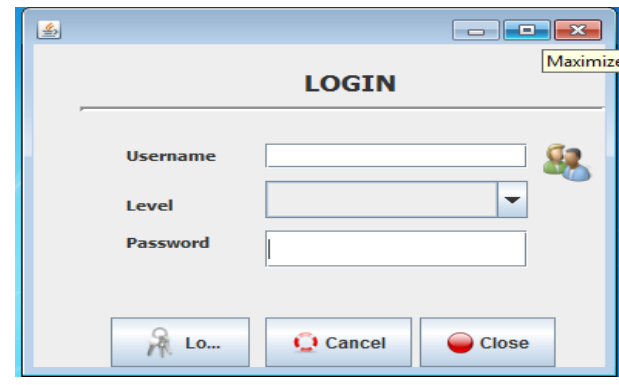

Gambar 2 Form Login

\section{A. Form Pendapatan}

Form ini merupakan form untuk mengentrikan data-data pendapatan. Dalam form ini dirancang beberapa tombol yaitu simpan, tambah, hapus, edit dan keluar. Tombol simpan berfungsi untuk menyimpan data yang dientrikan. Tombol tambah berfungsi untuk menambahkan data yang akan dientrikan. Tombol edit berfungsi untuk mengedit data yang ada. Tombol hapus berfungsi untuk menghapus data yang ada. Form input data biaya dapat dilihat pada gambar dibawah ini :

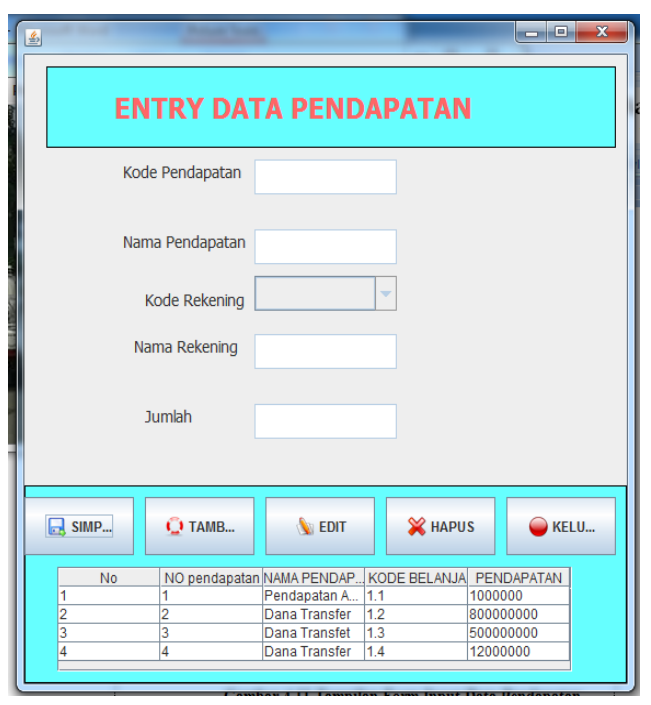

Gambar 3 Form Pendapatan

\section{B. Laporan Anggaran Pendapatan}

Laporan ini mencatat Anggaran Pendapatan Nagari Parit Malintang Kab. Padang Pariaman. Bentuk laporan pada sistem ini seperti pada gambar dibawah ini

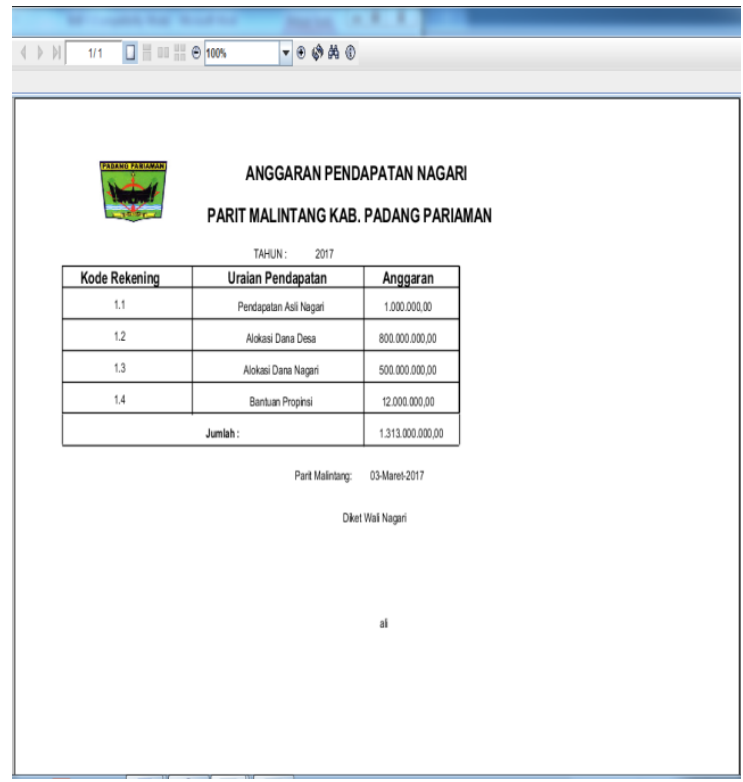

Gambar 4 Laporan Anggaran Pendapatan

\section{KESIMPULAN}

1. Mendapatkan aplikasi Sistem Informasi dengan menggunakan bahasa pemrograman Bahasa Java untuk pengolahan laporan keuangan dan menggunakan database MYSQL sebagai tempat penyimpanan datanya, maka laporan pengolahan laporan keuangan dapat dilakukan secara cepat dan akurat.

2. Memberi kemudahan pada Nagari Parit Malintang Kabupaten Padang Pariaman dalam pengelolaan laporan keuangan dengan cepat, tepat dan akurat

3. Dengan penerapan sistem yang baru maka akan dapat membantu pegawai dalam bekerja di era globalisasi ini yang serba modern.

\section{DAFTAR PUSTAKA}

Abdul Kadir, Pengenalan Sistem Informasi, Yogyakarta: Andi Offset, 2013.

Hanif Al-Fatta, Analisis \& perancangan system informasi, Offset,2007. 
http://octavianti92.blogspot.com/2013/01/peng ertian-sistem-informasi-dansistem.html,

Ifnu Bima, Java Desktop Aplikasi POS Berarsitektur Three Tier Menggunakan Swing, Hibernate, Dan Spring, Bogor: 2011.

Janner Simarmata, Iman Paryudi. Basis Data, Yogyakarta: Andi Offset, 2010.

Jogiyanto HM, Analisis dan Design Sistem Informasi, Yogyakarta: Andi Offset, 2009.

Jogiyanto HM, Pengenalan Komputer, Yogyakarta: Andi Offset, 2005.

Jurnal Al-Azhar Indonesia Seri Sains dan Teknologi, vol . 2, no. 2, september 2013.

Jurnal Angga Adhe Saputra, Sistem Informasi Berbasis Client Server, Semarang, 2014.

Nue Efendi Husda, Yvonne Wangdra, Pengantar Teknologi Informasi, Jakarta: Baduose Media,2016

Patrick Naughton, Konsep Dasar Pemrograman Java, terj. Panji Gotama, Yogyakarta: Andi, 2002.

Rosa AS, M. Shalahuddin, Modula Pembelajaran Rekayasa Perangkat Lunak, Modula, Yogyakarta: 2011.

Wahana Komputer, Seri Panduan Aplikasi Membuat Aplikasi Database Dengan Java 2, Yogyakarta: Andi Offset,2006. 